\title{
Mechanisms of Receptor Tyrosine-Protein Kinase ErbB-3 (ERBB3) Action in Human Neoplasia
}

Laurel E. Black, Jody F. Longo, and Steven L. Carroll

From the Department of Pathology and Laboratory Medicine, Medical University of South Carolina, Charleston, South Carolina

Accepted for publication

June 26, 2019.

Address correspondence to Steven L. Carroll, M.D., Ph.D., Department of Pathology and Laboratory Medicine, Medical University of South Carolina, 171 Ashley Ave., MSC 908, Charleston, SC 29425-9080. E-mail: carrolst@musc.edu.

\begin{abstract}
It is well established that the epidermal growth factor (EGF) receptor, receptor tyrosine-protein kinase erbB-2 (ERBB2)/human EGF receptor 2 (HER2), and, to a lesser extent, ERBB4/HER4, promote the pathogenesis of many types of human cancers. In contrast, the role that ERBB3/HER3, the fourth member of the ERBB family of receptor tyrosine kinases, plays in these diseases is poorly understood and, until recently, underappreciated. In large part, this was because early structural and functional studies suggested that ERBB3 had little, if any, intrinsic tyrosine kinase activity and, thus, was unlikely to be an important therapeutic target. Since then, however, numerous publications have demonstrated an important role for ERBB3 in carcinogenesis, metastasis, and acquired drug resistance. Furthermore, somatic ERBB3 mutations are frequently encountered in many types of human cancers. Dysregulation of ERBB3 trafficking as well as cooperation with other receptor tyrosine kinases further enhance ERBB3's role in tumorigenesis and drug resistance. As a result of these advances in our understanding of the structure and biochemistry of ERBB3, and a growing focus on the development of precision and combinatorial therapeutic regimens, ERBB3 is increasingly considered to be an important therapeutic target in human cancers. In this review, we discuss the unique structural and functional features of ERBB3 and how this information is being used to develop effective new therapeutic agents that target ERBB3 in human cancers. (Am J Pathol 2019, 189: 1898-1912; https://doi.org/10.1016/j.ajpath.2019.06.008)
\end{abstract}

Nearly four decades ago, a $170 \mathrm{kDa}$ cell surface glycoprotein was identified as the elusive receptor for epidermal growth factor (EGF). ${ }^{1}$ Shortly thereafter, it was recognized that the EGF receptor (EGFR) was encoded by the c-ERBBI proto-oncogene $e^{2,3}$ and that it was closely related to three other cell surface glycoproteins known as receptor tyrosineprotein kinase erbB-2 [ERBB2; alias c-Neu or human EGF receptor 2 (HER2)], ${ }^{4}$ ERBB3 (HER3), ${ }^{5,6}$ and ERBB4 (HER4). ${ }^{7}$ Today, these four glycoproteins are known as the ERBB family of receptor tyrosine kinases (RTKs). This family of growth factor receptors transmits signals from the extracellular milieu into the cellular interior, resulting in the activation of multiple cytoplasmic and nuclear signaling cascades that regulate myriad cellular functions. ERBB receptors are widely expressed in a variety of neuronal, epithelial, and mesenchymal cell types. ${ }^{8,9}$ In keeping with their wide expression, analyses of the phenotypes of knockout mouse models and results obtained in other experimental systems have demonstrated that ERBB receptors play key roles in the development of the cardiovascular, nervous, musculoskeletal, and other organ systems. It is also becoming increasingly apparent that ERBB receptors drive the pathogenesis of a wide variety of human cancer types. ${ }^{10}$ This has motivated the development of numerous therapeutic agents that target ERBB receptors, such as the monoclonal anti-ERBB2 antibodies trastuzumab and gefitinib, a small-molecular inhibitor of EGFR. To date, most studies examining the role that ERBB receptors play in cancer pathogenesis have focused on EGFR or ERBB2. Pharmaceutical development has paralleled this focus, emphasizing the development of agents that target EGFR or ERBB2.

Supported by National Institute of Neurological Disease and Stroke grant R01 NS048353; National Cancer Institute grant R01 CA122804; Department of Defense grants X81XWH-09-1-0086, W81XWH-11-1-0498, W81XWH-12-1-0164, W81XWH-14-1-0073, and W81XWH-15-1-0193; and Children's Tumor Foundation grants 2014-04-001 and 2015-05-007 (all to S.L.C.).

Disclosures: None declared. 
In comparison to EGFR and ERBB2, the functions of ERBB3 and ERBB4 and their role in human disease have been less well studied. In the case of ERBB3, this reflects, in part, the perception that ERBB3 is completely kinase dead. However, recent findings have begun to challenge this widely held perception. Furthermore, there is a growing body of evidence implicating ERBB3 in the pathogenesis of many human cancers. It is also becoming apparent that the physical interaction of ERBB3 with other ERBB receptors results in the formation of potently protumorigenic signaling complexes,${ }^{11}$ in large part because of the unique ability of ERBB3 to activate key cytoplasmic signaling pathways. These studies, together with the identification of numerous somatic and germline mutations in the ERBB3 gene in human cancers, are now fueling the functional characterization of key amino acid residues in this RTK. In light of these and other advances, it is understandable that several laboratories are now pursuing the development of new therapeutic agents that specifically target and inhibit ERBB3.

In this review, we discuss new findings about the unique functional characteristics of ERBB3 and its role in human carcinogenesis. To explain what makes ERBB3 special and how it differs from other ERBB family members, this review discusses the current updates of the ERBB family of RTKs, including their structure, their activating ligands, the structural changes induced by ligand binding, and how this leads to the formation of signaling complexes with distinct functional characteristics. The review also discusses the unique functional characteristics of ERBB3, including the disparate opinions regarding its tyrosine kinase activity, how its structural features modify its function during the formation of active signaling complexes, and the mechanisms by which ERBB3 activity is modulated. The review further details how ERBB3 signaling regulates cellular function, contrasting ERBB3 function in normal development with its function in cancer. This new understanding of ERBB3 action may guide the development of promising new therapeutic agents.

\section{The Structure, Upstream Activators, and Downstream Consequences of Activation of the ERBB Subfamily of RTKs}

The four members of the ERBB family of receptor tyrosine kinases (sometimes referred to as the epidermal growth factor receptor family) share a common structure that includes an $\mathrm{N}$-terminal extracellular ligand-binding domain (the ectodomain), a single transmembrane domain, an intracellular juxtamembrane domain, a tyrosine kinase domain, and a C-terminal tail; the latter three domains are collectively referred to as the endodomain. This shared structure reflects the fact that all four ERBB receptors function similarly - after EGFR, ERBB3, or ERBB4 bind a ligand, the ERBB receptors share the common property of interacting with one another, thereby activating their intrinsic tyrosine kinase activity (with the possible exception of ERBB3; see below), which, in turn, results in transphosphorylation of each receptor's endodomain ${ }^{12}$ and the recruitment of cytoplasmic signaling proteins that dock to these phosphorylated residues. Despite their similarities in structure and function, however, numerous studies have shown that the EGFR, ERBB2, ERBB3, and ERBB4 also have unique functional characteristics. In keeping with this, although the ERBB domains noted above show partial sequence homology, the precise amino acid sequence of each of these domains differs between ERBB family members. The degree of sequence divergence is variable from domain to domain - the domains with the highest degree of sequence homology are those that mediate overlapping functions shared by different ERBB receptors, whereas the least conserved domains are typically those that mediate distinct functions performed by individual ERBB family members. In addition, the size of these domains and the amino acid positions where they are located vary slightly between different ERBB receptors. Overall, the juxtamembrane and tyrosine kinase domains have the greatest degree of sequence homology (59\% to $81 \%$ sequence identity) among the ERBB family members. ${ }^{13}$ The high degree of sequence conservation in the ERBB tyrosine kinase domains undoubtedly reflects the constraints imposed by the enzymatic activity of this domain. Given this high degree of sequence homology, it is also not surprising that many small molecular ERBB inhibitors, which bind to the ATP-binding pocket in the tyrosine kinase domain, cross hit multiple ERBB receptors. In contrast, the ectodomain and the C-terminal tail are more structurally divergent. ${ }^{13}$ The limited conservation of the ectodomain reflects, in part, the fact that each ERBB receptor (with the exception of ERBB2) binds ligands that fall into overlapping sets. The C-terminal tail (12\% to $30 \%$ sequence identity) contains binding sites for specific docking proteins that orchestrate the activation or repression of downstream signal transduction pathways. The low sequence homology within the ERBB C-terminal tails is, thus, consistent with the observation that many of the intracellular signaling cascades regulated by specific ERBB receptors are unique to that receptor.

In addition, some ERBB genes generate structural variants in which alternative mRNA splicing introduces additional functional domains. Perhaps the best known of these are the structural variants of ERBB4. In addition to the regions noted above, ERBB4 can contain either of the two domains in the stalk region $\mathrm{N}$-terminal to the transmembrane domain that are known as juxtamembrane-A and juxtamembrane-B. Unlike juxtamembrane-B, juxtamembrane-A contains a site that can be targeted for proteolytic cleavage by tumor necrosis factor- $\alpha$ converting enzyme/ disintegrin and metalloproteinase domain-containing protein 17. ${ }^{14,15}$ Subsequent intramembranous cleavage by the $\gamma$ secretase complex ${ }^{16,17}$ releases the 80 -kDa ERBB4 intracellular domain into the cellular interior, where it can 
interact with mitochondria to promote apoptosis. ${ }^{18,19}$ The ERBB4 intracellular domain can also enter the nucleus, where it interacts with TGF- $\beta$-activated kinase 1 and MAP3K7-binding protein 2 and nuclear receptor corepressor 1 to form a transcriptional regulatory complex. ${ }^{20} \mathrm{In}$ addition, ERBB4 variants exist that differ in the presence or absence of an alternatively spliced intracellular 16 amino acid Cyt1 domain, ${ }^{21,22}$ which contains a docking site for the p85 regulatory subunit of phosphatidylinositol 3-kinase (PI3K). Although $\mathrm{we}^{23}$ and others ${ }^{24}$ have demonstrated that these ERBB4 variants modulate PI3K signaling, the physiological impact of this mode of ERBB4 signaling at an organismal level remains incompletely understood, a knowledge gap that hopefully will be filled by the analysis of ERBB4-Cyt $1^{\text {flox } f l o x}$ mice that we have recently developed in collaboration with Dr. Andres Buonanno (National Institute of Child Health and Human Development, Bethesda, MD). As is discussed below, splice variants that modify the structure of ERBB3 (eg, nuclear 50- and 80-kDa variants) also exist. Consequently, although the molecular weights usually cited for the different ERBB receptors (170 kDa for EGFR; $180 \mathrm{kDa}$ for ERBB2; $185 \mathrm{kDa}$ for ERBB3 and ERBB4) in most publications are certainly accurate, investigators can and do encounter ERBB proteins that differ significantly from these norms.

Except for ERBB2, multiple EGF family ligands can bind to the ectodomain of each of the ERBB receptors, resulting in their activation. On the basis of their relative affinity for individual ERBB receptors, EGF family ligands can be divided into three groups. The first group of ligands, which share the common property of binding only to EGFR, includes EGF, amphiregulin, transforming growth factor- $\alpha$, and epigen (Figure 1A). The second group of ligands, which can activate both EGFR and ERBB4, is represented by epiregulin, betacellulin, and heparin-binding EGF. The third group of EGF family ligands encompasses multiple splice

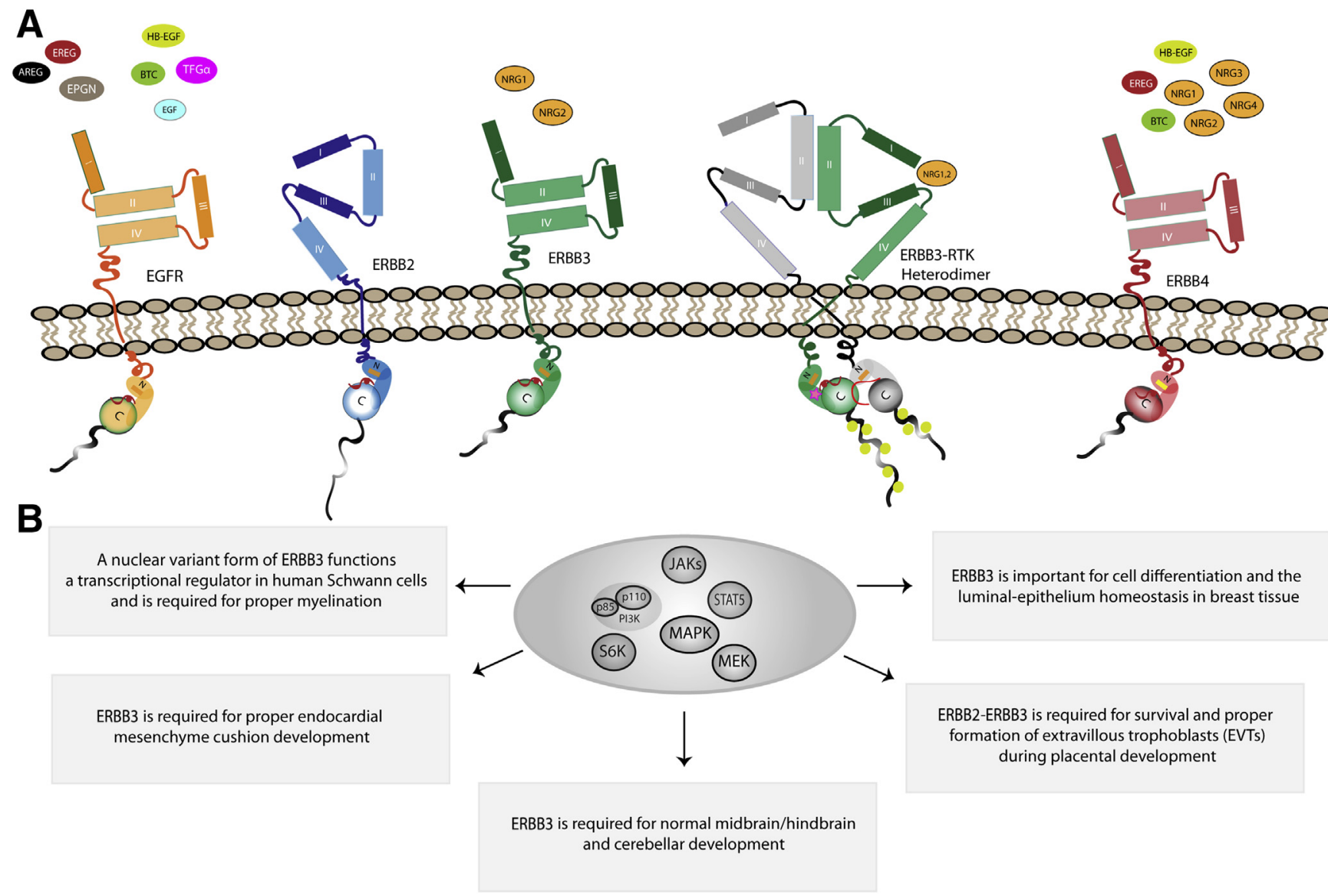

Figure 1 The ERBB family of receptor tyrosine kinases (RTKs) orchestrates biological processes via distinct ligands in normal cells. A: Each ERBB family member has distinct ligand-binding specificity. Epidermal growth factor receptor (EGFR; orange) is shown in the tethered (inactive) conformation with its potential ligands: amphiregulin (AREG), epiregulin (EREG), epigen (EPGN), EGF, heparin-binding epidermal growth factor (HB-EGF), betacellulin (BTC), and transforming growth factor- $\alpha$ (TGF- $\alpha$ ). ERBB2 (blue) is shown in its constitutive open conformation. ERBB3 (green) is shown in the tethered conformation with its potential ligands: neuregulin-1 and neuregulin-2 (NRG1 and NRG2, respectively). ERBB4 (red) is shown in the tethered conformation with its associated ligands: EREG, HB-EGF, NRG1, NRG2, NRG3, and NRG4. N and C in the intracellular domain indicate the N-lobe and C-lobe, respectively, of the tyrosine kinase domain, which flank the tyrosine kinase active site (red). B: Full-length ERBB3 as well as a 50-kDa nuclear variant of ERBB3 (not shown) regulates multiple critical biological functions in normal cells (indicated in each box). The oval in the center highlights ERBB3-regulated signaling pathways that have been implicated in the regulation of some of these biological functions. MAPK, mitogen-activated protein kinase; PI3K, phosphatidylinositol 3-kinase; S6K, ribosomal protein $\mathrm{S} 6$ kinase $\beta-1$. 
variants of neuregulin-1 (NRG1), NRG2, NRG3, and NRG4; this growth factor subfamily binds to both ERBB3 and ERBB4 (NRG1, NRG2) or to ERBB4 only (NRG3, NRG4). ${ }^{25}$ None of the EGF family ligands noted above bind directly to and activate ERBB2. However, mucin-4, a transmembrane protein that contains two EGF-like domains, can activate ERBB2 via direct interaction. For this to occur, ERBB2 and mucin-4 must be coexpressed in the same cell. $^{26}$

Unlike many other RTK ligands, EGF family ligands bind to the ectodomains of ERBB receptors as monomers rather than as dimers. Ligand binding occurs at specific sites in the ERBB receptor ectodomain. The ERBB receptor ectodomain can be subdivided into four functionally distinct subdomains (I to IV) (Figure 1A) whose conformation is shaped by disulfide bonds. ${ }^{27}$ Subdomains I and III (alias L1 and L2, respectively) are leucine-rich regions that mediate receptor binding of activating growth factors ${ }^{28,29}$; subdomains I and III have an amino acid sequence identity of only approximately $37 \%$ between the different ERBB receptors, consistent with the fact that each ERBB receptor binds different growth factors. Ligand binding to extracellular subdomains I and III of an ERBB receptor triggers conformational changes that ultimately result in the formation of an intracellularly asymmetric kinase dimer ${ }^{30,31}$ in which one partner contains bound ligand and the other partner does not (this is not to imply that the ligand does not ultimately come into contact with the second receptor subunit; some models indicate that the ligand does, in fact, form contacts with the second ERBB receptor recruited to the signaling complex).

ERBB receptor dimerization after ligand activation is mediated, in part, by the cysteine-rich (CR) subdomains II (CR1) and IV (CR2) of the ectodomain, the cysteine-rich regions that separate and follow subdomains I and III, respectively. ${ }^{29}$ With the exception of ERBB2, inactive ERBB receptors exist in a tethered conformation before ligand binding, where the dimerization arm loop of subdomain II binds to the subdomain IV tethering arm (Figure 1A), thereby preventing aberrant activation. ${ }^{29}$ The conformational changes induced by the binding of an EGF family ligand to subdomains I and III of an ERBB receptor include disruption of the contact loop between subdomains II and IV, which allows subdomains I and III to connect and, thus, stabilize the now extended conformation that is necessary for homodimerization or heterodimerization. $^{32}$ This nascent dimerization event is further stabilized by interactions between the transmembrane and juxtamembrane domains of the now partnered ERBB receptors ${ }^{33,34}$; GXXXG consensus sequences, which occur in pairs in all of the ERBB receptors except ERBB3, appear to play a particularly important role in mediating interactions between ERBB receptor transmembrane domains. ${ }^{35}$ In this newly formed asymmetric kinase dimer, intracellular asymmetric conformational changes occur that allow the C-terminal lobe of one of the kinases (the activator kinase) to contact the other (receiver) kinase's N-terminal lobe. This results in activation of the receiver tyrosine kinase domain. ${ }^{30}$

The ERBB tyrosine kinase domain contains four functional elements known as the $\mathrm{N}$-lobe, helix $\alpha \mathrm{C}$, the activation loop, and the C-lobe. All these tyrosine kinase elements play distinct roles in receptor activation. The active site of the tyrosine kinase domain is located between the $\mathrm{N}$ - and C-lobes (Figure 1A). In the inactive state, the $\mathrm{N}$ - and $\mathrm{C}$-lobes are more open; during activation, the lobes assume a closed conformation that properly positions ATP and the receptor's substrate within the binding pocket. ${ }^{36}$ This conformational shift is triggered in the kinase domain when the C-lobe of the activator kinase physically interacts with the $\mathrm{N}$-lobe of the receiver kinase and stabilizes $\mathrm{it}^{37}$; this stabilization is mediated by an interaction between the hydrophobic bottom region of the C-lobe of the activator kinase and the hydrophobic top region of the receiver kinase's N-lobe. ${ }^{38}$ The C-lobe of the activator kinase causes helix $\alpha \mathrm{C}$ in the receiver kinase to swing inwards toward its catalytic center, which further stabilizes the interaction and allows extension of the activation loop. ${ }^{39}$ The end result of these conformational changes is activation of the tyrosine kinase domain of the receiver kinase, which is then poised to perform trans or cis (auto) phosphorylation of tyrosine residues in the C-terminal tails of each receptor. ${ }^{40}$ Historically, the activator receptor has been considered to be the receptor that has bound ligand. This is controversial, however, and has been challenged by recent work indicating that activator-receiver preference in ERBB heterodimers is instead determined by the intracellular regions of the receptors. ${ }^{32}$

The specific tyrosine residues that are phosphorylated within the intracellular domains of the dimerized ERBB receptors are dictated by several factors, including the sequence of each receptor protein, which ERBB receptors dimerize, the activating ligand, receptor stoichiometry, and receptor expression levels at the plasma membrane as well as the presence of other extracellular matrix components. Which cytoplasmic signaling molecules are subsequently recruited to the signaling complex depends on which tyrosine residues are phosphorylated. The downstream signaling pathways known to be regulated by ERBB kinases in this manner include the PI3K/Akt, the Ras/RAF proto-oncogene serine/threonine-protein kinase/mitogen-activated protein kinase kinase 1/2 /extracellular signal-regulated kinase $1 / 2$, the Janus kinase/STAT, and the phospholipase $\mathrm{C} \gamma /$ protein kinase $\mathrm{C}$ pathways. ${ }^{41}$ As these downstream signaling pathways orchestrate many cellular processes that are essential for normal prenatal and postnatal development, ${ }^{42}$ it is not surprising that aberrant activity of ERBB receptors, triggered by overexpression or mutation, disrupts cellular homeostasis and triggers the development of multiple types of cancer.

As indicated above, which tyrosine residues are phosphorylated after ligand binding and receptor dimerization is 
determined, in part, by which ERBB receptors dimerize with one another. Preferred ERBB dimerization partners exist among the family members, with ERBB2 being the preferred dimerization partner for the other ERBB family members in most cellular contexts. This appears to reflect a conformational difference between nonactivated ERBB2 and other nonactivated ERBB receptors. In contrast to the EGFR, ERBB3, and ERBB4, which adopt a tethered intramolecular conformation in the absence of bound ligand, ERBB2 assumes a constantly active conformation in which subdomains II and IV are extended and are thought to be continuously available for interaction with other ERBB receptors, even in the absence of ligand stimulation. ${ }^{43}$ It is also likely that differences in the sequences of subdomains II and IV in other ERBB receptors play a role in determining which ERBB receptors are more likely to dimerize with each other. Subdomains II and IV are among the most divergent regions in the ERBB receptors, with an average amino acid sequence identity of only $17 \%$. Although the structural consequences of this extreme sequence variability remain incompletely understood, it is highly likely that this divergence translates into different preferences for receptor dimerization. Also, other factors modify the strength of ERBB receptor dimerization-a recent study elegantly demonstrated that which ligands bind to a receptor is also an important determinant of dimerization strength. ${ }^{44}$

A hierarchy also exists regarding which ERBB receptors are most likely to function as receiver kinases. Among the ERBB receptors, EGFR is the strongest receiver kinase, followed by ERBB2 and then ERBB4. In fact, ERBB4 functions only as a receiver when it homodimerizes with another ERBB4 receiver or when it heterodimerizes with ERBB3. This hierarchical process, which determines which ERBB kinase is activated and which ERBB kinase is subsequently phosphorylated within an ERBB homodimer or heterodimer, adds to the complexity and cellular control of the cytoplasmic signaling cascades regulated by ERBB receptors. $^{32,45}$

\section{Distinct Features of ERBB3, the Functional Peculiarities That Result from Its Structural Differences, and Its Key Regulatory Partners}

Studies of mice with targeted null mutations of the ERBB3 gene (ERBB3 knockout mice) provided some of the earliest evidence indicating that ERBB3 was functionally distinct from other ERBB family members (Figure 1B). Most $E R B B 3^{-1-}$ mice die in utero at embryonic day $13.5^{46,47}$ as a result of endocardial cushion defects that lead to blood reflux through defective valves ${ }^{47}$ as well as a loss of Schwann cell precursors. ${ }^{46}$ Multiple other abnormalities of the central and peripheral nervous system are also evident in $E R B B 3^{-1-}$ embryos, including a loss of dorsal root ganglia sensory neurons ${ }^{46}$ and spinal cord motor neurons ${ }^{46}$ as well as hypoplasia of the primary sympathetic ganglion chain ${ }^{48}$ and malformation of the midbrain and hindbrain with poor differentiation of the cerebellar plate. ${ }^{47}$ In contrast, $\mathrm{Nrgl}^{-1-}$, $E R B B 2^{-l-}$, and $E R B B 4^{-l-}$ mice die in utero at embryonic day 10.5 because of a failure of cardiac ventricular myocyte differentiation and show defects in their nervous systems that differ from those seen in $E R B B 3^{-1-}$ mice. ${ }^{47,49,50}$ At least some of these differences can be explained by differences in the cell types expressing each ERBB receptor and the ligands activating these receptors. However, when the expression of each ERBB receptor was mapped in the central nervous system via immunohistochemistry and in situ hybridization, many cell types in the areas impacted by ERBB receptor knockout were found to coexpress multiple ERBB receptors, indicating that they were not functionally redundant. ${ }^{9}$ Conditional ERBB3 knockout mice have implicated ERBB3 in additional functions, such as maintaining luminal-basal homeostasis in breast epithelium ${ }^{51}$; ERBB3 is also essential for the survival and proper formation of extravillous trophoblasts during placental development. ${ }^{52}$ Observations such as these have motivated several laboratories to take a closer look at the structural and functional characteristics of ERBB3.

ERBB3 contains 1342 amino acids and has a predicted molecular weight of $145 \mathrm{kDa}$. However, its observed mass is typically $185 \mathrm{kDa}$. This difference occurs because ERBB3 is heavily post-translationally glycosylated at 10 potential N-linked glycosylation sites (Figure 2). In this regard, it is similar to other ERBB receptors; approximately $30 \%$ of the mature molecular weight of EGFR (11 glycosylation sites), ERBB2 (7 glycosylation sites), and ERBB4 (9 glycosylation sites) is due to $\mathrm{N}$-glycosylation. This glycosylation is important for ligand-dependent and ligandindependent functions of mature ERBB receptors as well as protein stability and activation of downstream signaling events. ${ }^{53,54}$ However, it is also becoming apparent that sitespecific glycosylation has distinct effects on the function of each receptor. As an example, glycosylation of Asn-418 in ERBB3 prevents tumor progression by blocking aberrant uncontrolled dimerization of ERBB3 with ERBB2. ${ }^{55}$

In mature 185-kDa ERBB3 [the form after removal of the signal peptide (amino acids 1 to 19) and post-translational modification], the extracellular domain spans amino acids 20 to 630 , with the transmembrane domain encoded by residues 642 to 666 , the juxtamembrane domain encoded by amino acids 667 to 709 , the tyrosine kinase domain encoded by residues 709 to 965 (with the activation loop spanning amino acids 830 to 890 ), and the C-terminal tail being located at amino acids 990 to $1342 .{ }^{56}$ Several different isoforms of ERBB3 have been documented that vary from this structure. In prostate cancer, a truncated and secreted 45-kDa ERBB3 isoform [p45-sERBB3 (alias MDA-BF-1)] was discovered in bone metastases. ${ }^{57}$ ERBB3 expression in prostate cancer is both cytoplasmic and nuclear, with much higher nuclear staining evident in malignant tissue relative to nontransformed prostate tissue ${ }^{58}$; these observations are consistent with the presence of a nuclear 


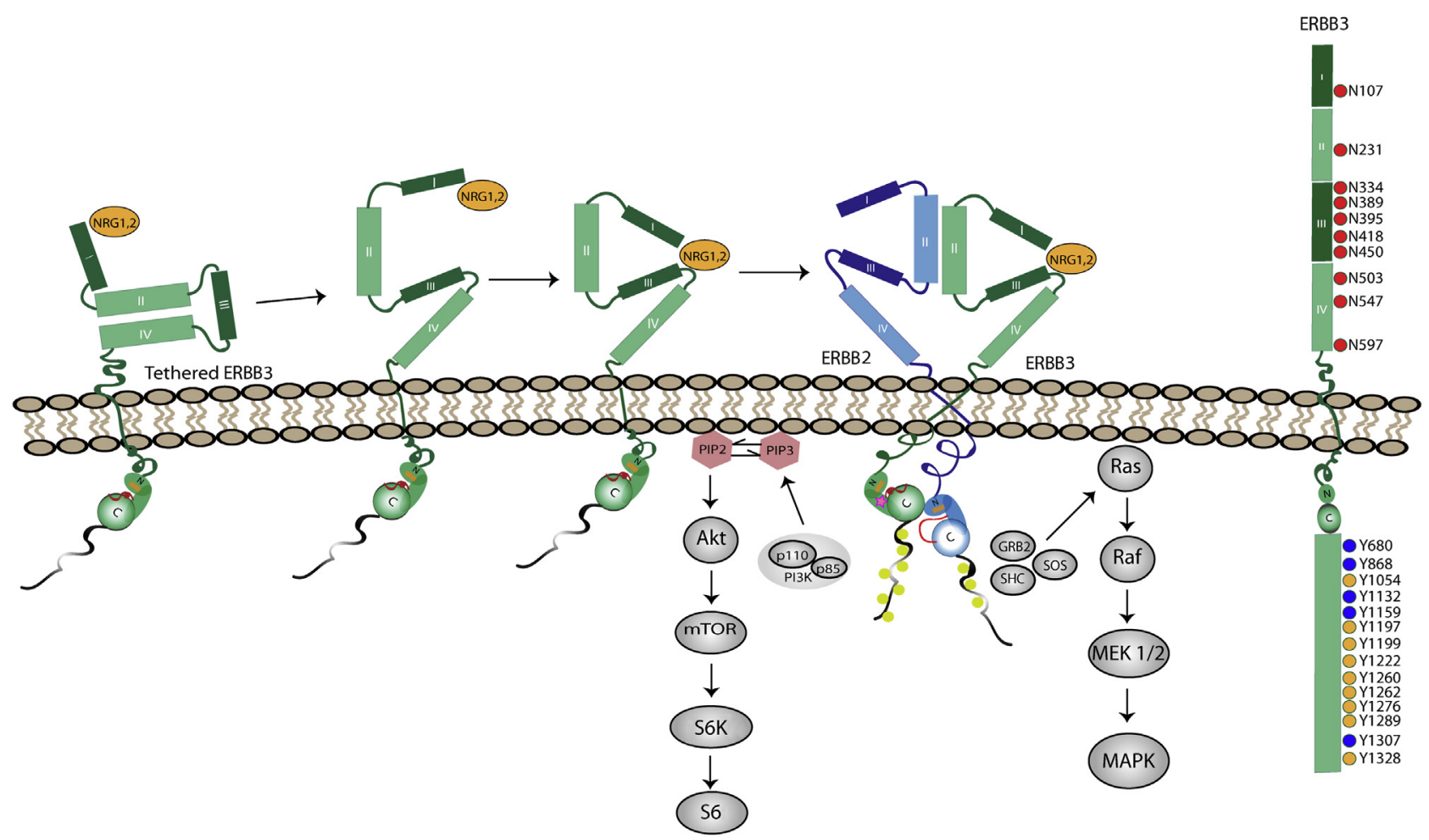

Figure 2 ErbB regulation of cellular survival and growth pathways. Ligand binding generates an untethered ERBB3 structure primed for heterodimerization. Left: ERBB3 in its tethered (inactive) conformation is structurally poised to bind ligand [neuregulin-1 (NRG1)/NRG2] within domain I of the ectodomain. Ligand binding induces a conformational change, bringing together domains I/III and allowing for heterodimerization with other ERBB receptors to occur. In this schematic, ERBB3 is the activator receptor and ERBB2 serves as the receiver receptor. Asymmetric dimer formation involves interaction between the bottom of the C-lobe on the activator receptor with the top of the $\mathrm{N}$-lobe of the receiver receptor, allowing for activation loop extension, followed by phosphorylation of each receptor's C-terminal tail. The phosphorylated receptors provide docking sites within their C-terminal tails for kinase-mediated signal transduction; signaling pathways activated as a result of these interactions are indicated in gray. Right: Schematic of key ERBB3 post-translational modifications. Red circles in the ectodomain represent the $10 \mathrm{~N}$-glycosylation sites in ERBB3; yellow circles, the nine functionally validated phosphorylation sites; blue circles, five additional tyrosines that may be phosphorylated but have not yet been shown to undergo this modification. GRB, growth factor receptor bound protein 2; MAPK, mitogen-activated protein kinase; MEK, mitogen-activated protein kinase kinase; mTOR, mammalian target of rapamycin; S6, ribosomal protein S6; S6K, ribosomal protein S6 kinase $\beta-1$; SHC, Src homology domain containing transforming protein; S0S, Son of Sevenless.

localization signaling near the ERBB3 C-terminus. The expression pattern of ERBB3 in Schwann cells also demonstrates cytoplasmic and nuclear localization. In Schwann cells, however, an alternative transcription initiation site leads to the production of a $50-\mathrm{kDa}$ truncated form of ERBB3. This truncated ERBB3 protein, which is referred to as the nuclear variant of ERBB3, contains the C-terminal nuclear localization site and, thus, localizes to Schwann cell nuclei. ${ }^{59}$ Chromatin immunoprecipitation-chip experiments have shown that the nuclear variant of ERBB3 associates with the promoters of several genes involved in myelination; inhibition of the nuclear variant of ERBB3 inhibits myelination and alters the distribution of ezrin within nodes of Ranvier. Although a similarly produced $80-\mathrm{kDa}$ ERBB3 variant was also observed, the functional characteristics of this variant in Schwann cells was unclear. However, in prostate $^{60}$ and lung carcinoma ${ }^{61}$ cells, this $80-\mathrm{kDa}$ ERBB3 variant similarly enters the nucleus and acts as a transcriptional regulator.

There are two key features of the $185-\mathrm{kDa}$ form of ERBB3 that impact its ability to dimerize with other ERBB receptors and form an active signaling complex. First,
ERBB3 possesses only one GXXXG consensus sequence in its transmembrane domain; other ERBB receptors have two GXXXG consensus sequences that mediate interactions between ERBB receptor transmembrane domains during dimerization, which potentially weakens ERBB3's ability to homodimerize. ${ }^{35}$ Second, the tyrosine kinase activity of ERBB3 is widely thought to be impaired compared with other ERBB family members. Although the ATP-binding site (GlyXGlyXXGly; amino acids 716 to 721 ) of ERBB3 is conserved, a key amino acid residue in the catalytic domain is altered in ERBB ${ }^{62}$; as a result of this Asp to Asn815 alteration, the kinase activity of ERBB3 is two orders of magnitude lower than that of EGFR. ${ }^{63}$ On the basis of these observations, it has been suggested that ERBB3 is a pseudokinase that functions as either a scaffold protein that mediates the assembly of signaling complexes or an allosteric regulator of other proteins. ${ }^{30,64,65}$ The combination of a single GXXXG consensus sequence and impaired tyrosine kinase activity potentially explains why ERBB3 homodimers are rarely, if ever, encountered as an active signaling complex (ERBB3 can, however, form oligomers when inactive; see below). 
The impaired tyrosine kinase activity of ERBB3 also has important implications for its ability to function as an activator or receiver in a signaling complex (Figure 2). As described above, the activation of the kinase domains in asymmetric ERBB dimers occurs when the C-lobe of the activator receptor physically interacts with the N-lobe of the receiver receptor and activates the tyrosine kinase domain of the receiver receptor. ${ }^{37}$ However, ERBB3 has mutations in key catalytic residues in its kinase domain and in the dimerization interface that prevent it from adopting a receiver position within an asymmetric kinase dimer. ERBB3 can, however, serve as an activator kinase because of other conserved residues within the interface, which explains why ERBB3 most likely does not form homodimers but functions well in heterodimeric pairs. ${ }^{66}$ This supposition is based on the prevalent view that active ERBB3 signaling complexes are represented by ERBB heterodimers. Some studies have suggested that active signaling complexes that include ERBB3 may take other forms. For instance, evidence has been presented arguing that ERBB2 and ERBB3 instead form tetrameric structures after ligand binding. ${ }^{65}$

Although many investigators believe that ERBB3 is kinase dead, there is not uniform agreement on this point. Shi et $\mathrm{al}^{67}$ have presented evidence that ERBB3 binds ATP and has weak tyrosine kinase activity despite the alterations in its tyrosine kinase domain. X-ray crystallography indicates that the activation loop of ATP-bound ERBB3 has a structure similar to that of inactive EGFR and ERBB4. ${ }^{67,68}$ This unique conformation may allow ERBB3 to activate its dimerization partner via an associative mechanism, rather than the more efficient dissociative mechanism; because activation via an associative mechanism is not as robust, this may explain the difficulty that ERBB3 has phosphorylating exogenous substrates. ${ }^{67}$ Consistent with this suggestion, a quantum mechanics/molecular mechanics simulation study argued that ERBB3 catalyzes phosphorylation via a mechanism distinct from that used by other ERBB family members. This study indicated that the hydrophobic interface that ERBB3 forms with partner receptors facilitates allosteric transactivation of its dimerization partner, thereby eliminating the requirement for strong intrinsic HER3 kinase activity. ${ }^{69}$ At present, we cannot rule out the possibility that this model represents an alternative and distinct mode of ERBB3 signaling.

That is not to say that ERBB3 is ineffective in signaling-indeed, ERBB2-ERBB3 heterodimers are the most potent transforming ERBB signaling complex encountered in a plethora of cancers. ${ }^{70}$ ERBB3's intracellular domain contains nine tyrosines with known functional impact when phosphorylated (Y1054, Y1197, Y1199, Y1222, Y1260, Y1262, Y1276, Y1289, and Y1328) (Figure 2) and an additional five sites that can be phosphorylated but whose function is unknown (Y680, Y868, Y1132, Y1159, and Y1307) (Figure 2). Any combination of these tyrosines can be phosphorylated to drive downstream signal transduction pathways. Six of these phosphorylated tyrosine (Y1054, Y1197, Y1222, Y1260, Y1276, and Y1289) residues serve as docking sites for the p85 regulatory subunit of PI3K. ${ }^{71}$ Consequently, ERBB3 is a highly potent activator of the PI3K pathway that drives the pathogenesis of multiple cancer types. However, ERBB3 also activates other signaling pathways by providing docking sites for Src family members, She (Y1328) and Grb2 (Y1199, Y1262), an adapter protein that binds Son of Sevenless, a guanine nucleotide exchange factor that activates Ras proteins. In addition, ERBB3 contains multiple serine and threonine residues that can be phosphorylated. The proteins mediating phosphorylation of these serine and threonine residues and the consequences of these phosphorylation events remain incompletely understood.

The half-life of ERBB3, which impacts the period and amplitude of signal transduction after activation, is heavily dependent on receptor recycling and $\mathrm{N}$-linked glycosylation and/or degradation; this occurs both in a ligand-dependent and ligand-independent manner. ${ }^{72}$ It has been suggested that inactive ERBB3 exists in oligomerized pools that form via a ligand-independent mechanism in the plasma membrane. In this model, NRG1 $\beta$ binding to ERBB3 destabilizes these oligomers, freeing ERBB3 to heterodimerize with a partner (typically ERBB2). ${ }^{73}$ However, this model has been recently challenged by a study that indicated that NRG1 $\beta$ stimulation, rather than decreasing ERBB3 oligomerization/ clustering, increased ERBB3 clustering when it was coexpressed with EGFR or ERBB2. ${ }^{74}$

Ligand binding also affects ERBB3 stability. In the absence of ligand, ERBB3 has a half-life of approximately 2.5 to 3.5 hours at the plasma membrane. ${ }^{72}$ After NRG1 $\beta$ stimulation, however, the half-life of ERBB3 is reduced to approximately 0.5 hours. $^{75}$ In addition, the half-life of ERBB3 can be modified by other cellular proteins. For instance, the $\mathrm{E} 3$ ubiquitin protein ligase, ring finger protein 41 (Nrdp1/RNF41), results in increased ERBB3 expression in many breast cancers. ${ }^{76}$ With the exception of ERBB4, which undergoes ligand-induced endocytosis, all ERBB receptors undergo constitutive endocytosis at a relatively slow rate (approximately $1 \%$ to $2 \%$ /minute).$^{77}$ ERBB3 is endocytosed by both clathrin-mediated and clathrin-independent endocytosis. Interestingly, cytoplasmic trafficking favors the fast clathrin-dependent endocytosis pathway, whereas nuclear translocation of ERBB3 relies heavily on the highcapacity clathrin-independent pathway. ${ }^{78}$ This provides yet another mechanism by which ERBB3 levels in the cytoplasm and nucleus can be independently adjusted, thereby allowing ERBB3 regulated cytoplasmic signaling to be modified independent of nuclear signaling.

\section{ERBB3 in Human Cancer}

Over the past two decades, it has become increasingly evident that ERBB3 plays a key role in cancer biology. This appreciation was initially driven by findings, such as 
the observation that ERBB3 has an important role in ERBB2-driven breast cancer (although the mechanism by which this occurred was, at the time, unknown). ${ }^{79}$ ERBB2ERBB3 heterodimers were subsequently shown to regulate several key functions in human cancers, such as proliferation, migration, and tumor cell survival ${ }^{80}$ However, other ERBB3-containing dimers are key drivers of neoplasia in other settings. For example, ERBB3 serves as a powerful mediator of EGFR-dependent proliferation in pancreatic cancer, ${ }^{81}$ in large part because this allows EGFR to promote PI3K signaling via dimerization with ERBB3. An association study that examined the expression of all four ERBB receptors and their interacting partners in 159 samples from 79 tissues found that ERBB3 is usually coexpressed with ERBB2 and EGFR or ERBB2 and ERBB4 receptors. ${ }^{82}$ As ERBB3 is similarly coexpressed with other ERBB family members in human cancers,,${ }^{10}$ it clearly has the opportunity to form multiple heterodimers in these neoplasms.

Among the ERBB receptors, cancer-associated mutations have been most often found in EGFR and ERBB2, followed by ERBB3 and then ERBB4. ${ }^{83}$ Our review of the Catalog of
Somatic Mutations In Cancer (COSMIC) database indicates that ERBB3 is mutated and/or overexpressed in a wide variety of cancers, including several types of adenocarcinomas (breast, urinary tract, stomach, large intestine, biliary tract, bladder, endometrium, ovarian, uterine cervical, prostate, lung), melanomas, and gliomas; overexpression is often associated with copy number gains that encompass the $E R B B 3$ gene. In contrast, COSMIC did not report any tumor types with ERBB3 copy number loss and only a small fraction of cancers had lowered ERBB3 expression (liver, endometrium, breast, and prostate). Although mutations occur at multiple sites, the vast majority of cancerassociated ERBB3 mutations are missense mutations that occur in subdomains II (approximately 169 to 332 residues) and IV (approximately 353 to 475 residues) of the extracellular domain (Figure 3A). In contrast, fewer mutations have been found in the ERBB3 tyrosine kinase domain. Experimental validation of the functional significance of ERBB3 mutations has been limited. However, V104M, A232V, P262H/S, G284R, T389K, Q809R, S846I, and E928G were shown to promote anchorage-independent growth compared with wild-type controls in the presence

A
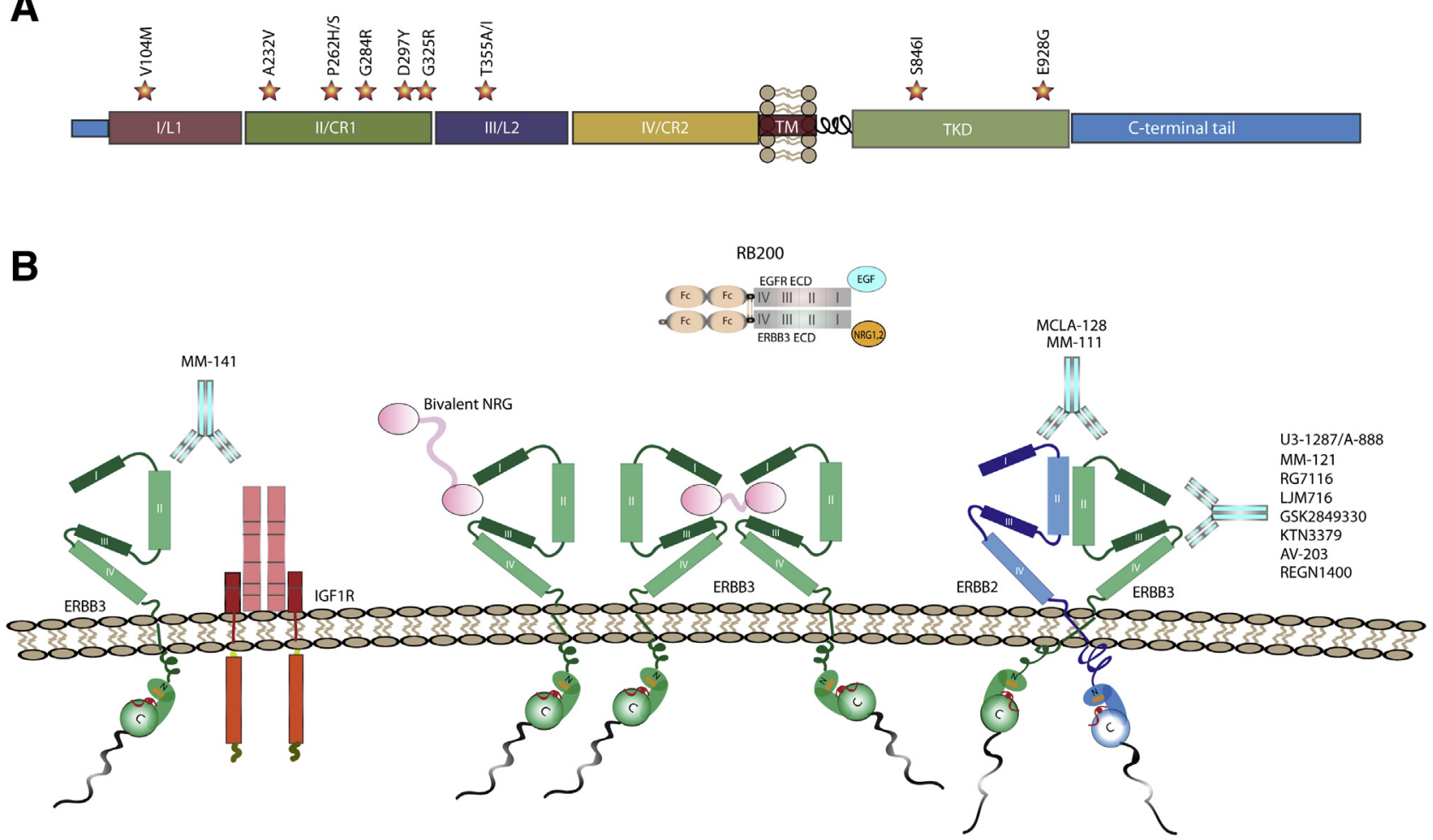

Figure 3 Current therapies against ERBB3 target the mutationally enriched extracellular domain. A: Hot spots for ERBB3 mutation in human cancers. Stars indicate the location of the mutations, with the specific amino acid change noted above each star. Most of these mutations occur in the extracellular domain rather than in the tyrosine kinase domain. B: Monoclonal antibodies are depicted as follows: patritumab/U3-1287/AMG888/unknown binding domain, seribantumab/MM-121/unknown binding domain, lumretuzumab/RG7116/R05479599 binds domain I, elgemtumab/LJM716 binds between domains II and IV, GSK2849330 binds domain III, KTN3379 (Kolltan Pharmaceuticals, New Haven CT)/CDX-3379 (Celldex Therapeutics, Hampton, NJ), AV-203/unknown binding domain, and REGN1400/unknown binding domain. Bivalent antibodies shown are MM-111 and MCLA-128, which will target both ERBB2 and ERBB3, along with MM-141, which will target IGF1R and ERBB3. Other targeting methods shown include the bivalent neuregulin (NRG) to tether ERBB3 receptors, so that they cannot bind another receptor tyrosine kinase, and RB200, which is a bispecific ligand trap consisting of the full-length extracellular domains of both ERBB3 and epidermal growth factor receptor (EGFR) and an Fc-mediated ligand-binding domain for ERBB3 and EGFR. IGF1R, insulin-like growth factor 1 receptor. 
of ERBB2; the T355I mutation has similar effects in the absence of ERBB2. ${ }^{83,84}$ Approximately half of all ERBB3 point mutations are G-to-A or A-to-G transitions; the other half are G-to-T transversions or C-to-T transitions.

ERBB3 signaling in cancer is additionally diversified by cross talk with other RTKs and by the diverse ligands that can activate it. ERBB3 can form complexes with insulinlike growth factor 1 receptor (IGF1R), fibroblast growth factor receptor 2, and MET proto-oncogene, receptor tyrosine kinase (HGFR/c-MET) in both ligand-dependent and ligand-independent manners. ${ }^{85}$ The ERBB3 ligands NRG1 and NRG2 drive ERBB3 signaling in a variety of cancers, including breast, ovarian, colorectal, non-small-cell lung carcinoma, prostate, and head and neck squamous cell carcinoma, via overexpression and act in an autocrine, juxtacrine, and paracrine manner. ${ }^{86}$ The NRG1 and NRG2 genes cause, via alternative splicing and the use of multiple promoters, numerous isoforms. Although incompletely studied, there is evidence indicating that these different NRG isoforms exert different biological effects when they activate ERBB3 signaling.

It is likely that we currently underestimate how widely ERBB3 is expressed in human cancers. In part, this reflects the fact that detecting ERBB3 protein expression can be challenging because of its short half-life after activation. However, provocative recent studies suggest that the widespread use of two-dimensional cell culture models to study ERBB3 expression, function, and drug responsiveness may also be a factor. Relative to two-dimensional monolayer cultures, ERBB3 protein expression is much higher in multicellular aggregate three-dimensional cultures of head and neck squamous carcinomas; furthermore, ERBB3 signaling pathways operate continuously in multicellular aggregate cultures despite low levels of ERBB2 and EGFR expression. ${ }^{87}$ Responses to drugs targeting ERBB receptors also differ between two-dimensional monolayer and multicellular aggregate cultures. ${ }^{88}$ Although relatively few such comparisons have been performed to date, it will be important to bear in mind the impact of culture methods as we continue to dissect the role that ERBB3 plays in human cancer and assess new therapeutic agents targeting this receptor tyrosine kinase.

\section{Approaches Used to Develop New Therapeutic Agents Targeting ERBB3}

Our growing understanding of how ERBB3 functions has paved the way for the development of several therapeutic strategies targeting ERBB3 in human cancers (Figure 3B). These strategies include: i) generating soluble receptors (ligand traps) that bind ERBB3 ligands (eg, RB200 ${ }^{89}$ ), thereby making them unavailable for binding to ERBB3 receptors expressed by tumor cells; ii) designing bivalent ligands (eg, bivalent NRG1) that promote ERBB3 homodimerization at the expense of heterodimerization with other
ERBB receptors; iii) blocking the ligand binding sites of ERBB3; iv) promoting ERBB3 destruction by internalization or other means; v) locking ERBB3 in a tethered conformation; or vi) using immunotherapy that targets ERBB3-expressing tumor cells. ${ }^{90}$ Broadly speaking, the agents used to block ligand binding, promote ERBB3 destruction, or lock ERBB3 in a tethered conformation are most often monoclonal antibodies. ${ }^{90} \mathrm{~A}$ wide variety of these agents are currently in clinical trials for multiple cancer types (Table 1). However, these are not the only type of agents that effectively target ERBB3. Antisense oligonucleotides, such as EZN-3920, reduce ERBB3 expression, the activation of ERBB3-dependent signaling pathways, and in vivo tumor growth, ${ }^{91}$ particularly when used in combination with small molecular ERBB inhibitors, such as lapatinib (targets EGFR and ERBB2) or gefitinib (targets EGFR). Small-molecule inhibitors that bind to the ATPbinding pocket of ERBB3 (TX1-85-1, TX-121-1) also effectively promote ERBB3 degradation, interfere with ERBB3 heterodimerization, and inhibit ERBB3-dependent pathways. $^{92}$ Anti-ERBB3 antibodies conjugated to cytotoxic drugs, such as saponin, ${ }^{93}$ monomethyl auristatin $\mathrm{F},{ }^{94}$ and the topoisomerase I inhibitor DXd (exatecan derivative for ADC), ${ }^{95}$ have shown promise in mouse cancer models and human cancer cell lines. Finally, vaccines using peptides derived from ERBB3 exert antitumor effects against breast and pancreatic cancers. ${ }^{96}$

The observation that ERBB3 physically interacts with other receptor tyrosine kinases has led several laboratories to develop agents that simultaneously target ERBB3 and these other receptors. Some of these studies have been motivated by a growing awareness that interactions between ERBB kinases and other proteins contribute to resistance to ERBB-targeted therapeutics. For instance, Martins et $\mathrm{al}^{97}$ have shown that in non-HER2 amplified breast cancers, ERBB3/IGF1R heterodimerization is driven by heat shock protein 90 inhibitor treatment; these tumors are sensitive to combinatorial therapy targeting ERBB3 and IGF1R. In other settings, drug resistance arises when ERBB3 stabilizes PI3K and mitogenactivated protein kinase pathway activation that was previously driven by MET amplification, HER2 amplification (which drives ligand-independent activation of ERBB3), or $N R G 1$-fusion gene mediated ERBB3 activation. ${ }^{85}$ Similarly, gefitinib-sensitive lung cancer can develop therapeutic resistance via $M E T$ amplification, which, in turn, drives ERBB3-dependent activation of the PI3K pathway; an antiERBB3 antibody conjugate with a novel topoisomerase I inhibitor (DXd), termed U3-1402, overcomes this ERBB3driven resistance in non-small-cell lung carcinoma. ${ }^{95}$ Observations such as these have motivated the development of monoclonal antibodies, such as MM-141, that simultaneously target ERBB3 and another receptor tyrosine kinase (IGF1 receptor in this case) (Figure 3B and Table 1). Interactions with other ERBB receptors also contribute to resistance to agents targeting an individual ERBB receptor. For instance, shortly after it was established that ERBB3 
Table 1 Anti-ERBB3 Monoclonal and Bispecific Antibodies Currently in Clinical Trials

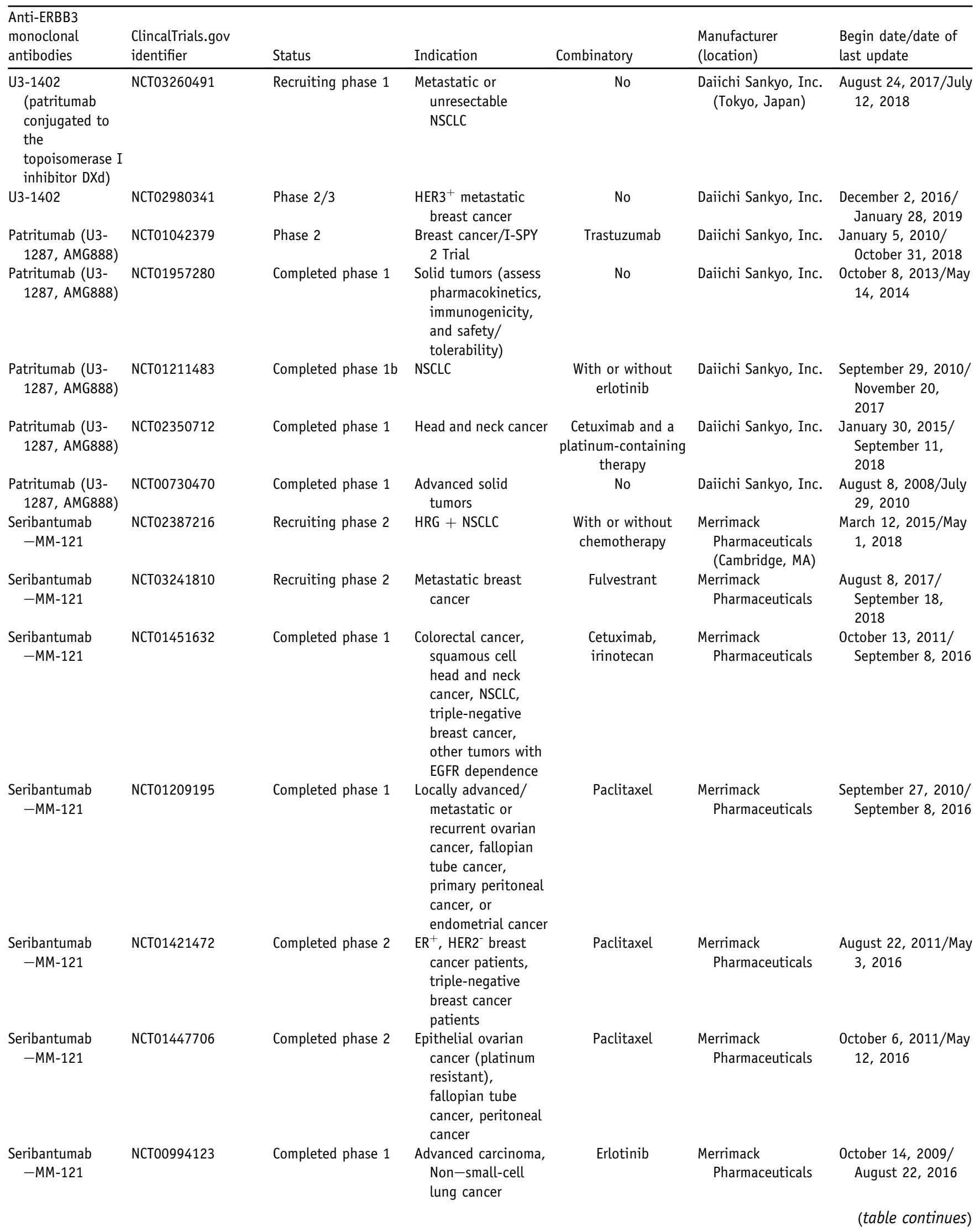


Table 1 (continued)

\begin{tabular}{|c|c|c|c|c|c|c|}
\hline $\begin{array}{l}\text { Anti-ERBB3 } \\
\text { monoclonal } \\
\text { antibodies }\end{array}$ & $\begin{array}{l}\text { ClincalTrials.gov } \\
\text { identifier }\end{array}$ & Status & Indication & Combinatory & $\begin{array}{l}\text { Manufacturer } \\
\text { (location) }\end{array}$ & $\begin{array}{l}\text { Begin date/date of } \\
\text { last update }\end{array}$ \\
\hline $\begin{array}{c}\text { Seribantumab } \\
\text {-MM-121 }\end{array}$ & NCT01151046 & Completed phase 2 & $\begin{array}{l}\text { HER2-negative breast } \\
\text { cancer patients }\end{array}$ & $\begin{array}{l}\text { With or without } \\
\text { exemestane }\end{array}$ & $\begin{array}{l}\text { Merrimack } \\
\text { Pharmaceuticals }\end{array}$ & $\begin{array}{l}\text { June } 25,2010 / \text { May } \\
\quad 12,2016\end{array}$ \\
\hline $\begin{array}{l}\text { Seribantumab } \\
-M M-121\end{array}$ & NCT01447225 & Completed phase 1 & $\begin{array}{l}\text { Advanced solid } \\
\text { tumors }\end{array}$ & $\begin{array}{l}\text { With or without } \\
\text { carboplatin, } \\
\text { pemetrexed, } \\
\text { cabazitaxel, or } \\
\text { gemcitabine }\end{array}$ & $\begin{array}{l}\text { Merrimack } \\
\quad \text { Pharmaceuticals }\end{array}$ & $\begin{array}{l}\text { October 6, 2011/ } \\
\text { September 14, } \\
2016\end{array}$ \\
\hline $\begin{array}{l}\text { Seribantumab } \\
\quad-\text { MM-121 }\end{array}$ & NCT01436565 & Completed phase 1 & Solid tumors & SAR245408 & $\begin{array}{l}\text { Merrimack } \\
\text { Pharmaceuticals }\end{array}$ & $\begin{array}{c}\text { September 19, 2011/ } \\
\text { June } 13,2014\end{array}$ \\
\hline LJM716 & NCT02167854 & $\begin{array}{l}\text { Active, not recruiting } \\
\text { phase } 1\end{array}$ & $\begin{array}{c}\text { Metastatic HER2 }^{+} \\
\text {breast cancer }\end{array}$ & $\begin{array}{l}\text { BYL719 and } \\
\text { trastuzumab }\end{array}$ & $\begin{array}{l}\text { Novartis (Basel, } \\
\text { Switzerland) }\end{array}$ & $\begin{array}{l}\text { June 19, 2014/ } \\
\text { October 22, } 2018\end{array}$ \\
\hline LJM716 & NCT01602406 & Completed phase 1 & $\begin{array}{l}\text { Advanced HER2- } \\
\text { positive breast } \\
\text { cancer or gastric } \\
\text { cancer }\end{array}$ & Trastuzumab & Novartis & $\begin{array}{l}\text { May } 21,2012 / \text { July } \\
26,2018\end{array}$ \\
\hline LJM716 & NCT01822613 & Completed phase 1 & $\begin{array}{l}\text { Esophageal squamous } \\
\text { cell carcinoma }\end{array}$ & BYL719 & Novartis & $\begin{array}{l}\text { April 2, 2013/June 1, } \\
\quad 2017\end{array}$ \\
\hline LJM716 & NCT01598077 & Completed phase 1 & $\begin{array}{l}\text { Squamous cell } \\
\text { carcinoma of head } \\
\text { and neck, HER2 }{ }^{+} \\
\text {breast cancer, or } \\
\text { gastric cancer }\end{array}$ & & Novartis & $\begin{array}{l}\text { May 15, 2012/April } \\
\text { 23, } 2014\end{array}$ \\
\hline AV-203 & NCT01603979 & Completed phase 1 & $\begin{array}{l}\text { Advanced solid } \\
\text { tumors }\end{array}$ & & $\begin{array}{l}\text { AVEO Oncology } \\
\quad(\text { Cambridge, MA) }\end{array}$ & $\begin{array}{l}\text { May 23, 2012/April 8, } \\
\quad 2015\end{array}$ \\
\hline REGN1400 & NCT01727869 & Completed phase 1 & $\begin{array}{l}\text { Unresectable or } \\
\text { metastatic cancer }\end{array}$ & $\begin{array}{l}\text { With or without } \\
\text { erlotinib, cetuximab }\end{array}$ & $\begin{array}{l}\text { Regeneron } \\
\text { Pharmaceuticals } \\
\text { (Tarrytown, NY) }\end{array}$ & $\begin{array}{l}\text { Nov 16, 2012/April 6, } \\
\quad 2015\end{array}$ \\
\hline GSK2849330 & NCT01966445 & Completed phase 1 & $\begin{array}{l}\text { Advanced HER3- } \\
\text { positive solid } \\
\text { tumors }\end{array}$ & & $\begin{array}{l}\text { GlaxoSmithKline } \\
\text { (Brentford, UK) }\end{array}$ & $\begin{array}{c}\text { October 21, 2013/ } \\
\text { July 19, } 2018\end{array}$ \\
\hline GSK2849330 & NCT02345174 & Completed phase 1 & $\begin{array}{l}\text { Immuno-positron } \\
\text { emission } \\
\text { tomography study } \\
\text { of } \mathrm{HER}^{+} \text {tumors }\end{array}$ & & GlaxoSmithKline & $\begin{array}{l}\text { January } 26,2015 / \\
\text { September 13, } \\
2018\end{array}$ \\
\hline $\begin{array}{l}\text { Lumretuzumab/ } \\
\text { RG7116/ } \\
\text { R05479599 }\end{array}$ & NCT01918254 & Completed phase 1 & $\begin{array}{l}\mathrm{HER}^{+}{ }^{+}, \mathrm{HER}^{+} \\
\text {metastatic breast } \\
\text { cancers }\end{array}$ & $\begin{array}{l}\text { Paclitaxel, } \\
\text { pertuzumab }\end{array}$ & $\begin{array}{l}\text { Hoffmann-La Roche } \\
\text { (Basel, } \\
\text { Switzerland) }\end{array}$ & $\begin{array}{l}\text { August 7, 2013/ } \\
\text { September 12, } \\
2017\end{array}$ \\
\hline $\begin{array}{l}\text { Lumretuzumab/ } \\
\text { RG7116/ } \\
\text { R05479599 }\end{array}$ & NCT01482377 & Completed phase 1 & $\begin{array}{l}\mathrm{HER}^{+} \text {solid tumors } \\
\text { of epithelial cell } \\
\text { origin }\end{array}$ & $\begin{array}{l}\text { With or without } \\
\text { cetuximab, erlotinib }\end{array}$ & Hoffmann-La Roche & $\begin{array}{c}\text { November } 30,2011 / \\
\text { January } 27,2017\end{array}$ \\
\hline KTN3379 & NCT02456701 & Completed phase 1 & $\begin{array}{l}\text { BRAF mutant thyroid } \\
\text { cancers }\end{array}$ & Vemurafenib & $\begin{array}{l}\text { Celldex Therapeutics } \\
\text { (Hampton, NJ) }\end{array}$ & $\begin{array}{l}\text { May } 28,2015 / \\
\text { September 5, } 2017\end{array}$ \\
\hline KTN3379 & NCT02014909 & Completed phase 1 & Advanced tumors & & Celldex Therapeutics & $\begin{array}{l}\text { December 18, 2013/ } \\
\text { July 24, } 2017\end{array}$ \\
\hline KTN3379 & NCT02473731 & Completed phase 1 & $\begin{array}{l}\text { Squamous cell } \\
\text { carcinoma of the } \\
\text { head and neck }\end{array}$ & & Celldex Therapeutics & $\begin{array}{l}\text { June } 17,2015 / \text { May } \\
\quad 12,2017\end{array}$ \\
\hline
\end{tabular}

\begin{tabular}{|c|c|c|c|c|c|c|}
\hline $\begin{array}{l}\text { Bispecific } \\
\text { antibodies }\end{array}$ & $\begin{array}{l}\text { ClincalTrials.gov } \\
\text { identifier }\end{array}$ & Status & Indication & Combinatory & Manufacturer & $\begin{array}{l}\text { Begin date/date of } \\
\text { last update }\end{array}$ \\
\hline $\begin{array}{l}\text { Duligotuzumab } \\
\text { (MEHD7945A), } \\
\text { EGFR and ERBB3 } \\
\text { targeted }\end{array}$ & NCT01986166 & Completed phase 1 & $\begin{array}{l}\text { Locally advanced or } \\
\text { metastatic cancers } \\
\text { with mutant KRAS }\end{array}$ & Cobimetinib & $\begin{array}{l}\text { Genentech, Inc. (San } \\
\text { Francisco, CA) }\end{array}$ & $\begin{array}{l}\text { November } 18,2013 / \\
\text { July } 18,2016\end{array}$ \\
\hline $\begin{array}{l}\text { Duligotuzmab } \\
\text { (MEHD7945A), } \\
\text { EGFR and ERBB3 } \\
\text { targeted }\end{array}$ & NCT01207323 & Completed phase 1 & $\begin{array}{l}\text { Locally advanced or } \\
\text { metastatic } \\
\text { epithelial tumors }\end{array}$ & & Genentech, Inc. & $\begin{array}{l}\text { September 22, 2010/ } \\
\text { May 1, } 2018\end{array}$ \\
\hline $\begin{array}{l}\text { Duligotuzmab } \\
\text { (MEHD7945A), } \\
\text { EGFR and ERBB3 } \\
\text { targeted }\end{array}$ & NCT01911598 & Completed phase 1 & $\begin{array}{l}\text { Recurrent/metastatic } \\
\text { squamous cell } \\
\text { carcinoma of the } \\
\text { head and neck }\end{array}$ & $\begin{array}{l}\text { Cisplatin and 5- } \\
\text { fluorouracil or } \\
\text { paclitaxel and } \\
\text { carboplatin }\end{array}$ & Genentech, Inc. & $\begin{array}{l}\text { July } 30,2013 / \text { July } 6 \\
\quad 2017\end{array}$ \\
\hline
\end{tabular}


Table 1 (continued)

\begin{tabular}{|c|c|c|c|c|c|c|}
\hline $\begin{array}{l}\text { Bispecific } \\
\text { antibodies }\end{array}$ & $\begin{array}{l}\text { ClincalTrials.gov } \\
\text { identifier }\end{array}$ & Status & Indication & Combinatory & Manufacturer & $\begin{array}{l}\text { Begin date/date of } \\
\text { last update }\end{array}$ \\
\hline $\begin{array}{l}\text { Duligotuzmab } \\
\text { (MEHD7945A), } \\
\text { EGFR and ERBB3 } \\
\text { targeted }\end{array}$ & NCT01652482 & Completed phase 2 & $\begin{array}{l}\text { KRAS wild-type } \\
\text { metastatic } \\
\text { colorectal cancer }\end{array}$ & 5-Fluorouracil & Genentech, Inc. & $\begin{array}{l}\text { July } 30,2012 / \\
\quad \text { November 2, } 2016\end{array}$ \\
\hline $\begin{array}{l}\text { Duligotuzmab } \\
\text { (MEHD7945A), } \\
\text { EGFR and ERBB3 } \\
\text { targeted }\end{array}$ & NCT01577173 & Completed phase 2 & $\begin{array}{l}\text { Recurrent/metastatic } \\
\text { squamous cell } \\
\text { carcinoma of the } \\
\text { head and neck }\end{array}$ & & Genentech, Inc. & $\begin{array}{l}\text { April 13, 2012/ } \\
\quad \text { November 2, } 2016\end{array}$ \\
\hline $\begin{array}{l}\text { MM-111 ERBB2 } \\
\text { and ERBB3 } \\
\text { targeted }\end{array}$ & NCT01097460 & Completed phase 1 & $\begin{array}{l}\text { Advanced HER2 } \\
\text { amplified, } \\
\text { heregulin-positive } \\
\text { breast cancer }\end{array}$ & Herceptin & $\begin{array}{l}\text { Merrimack } \\
\quad \text { Pharmaceuticals }\end{array}$ & $\begin{array}{l}\text { April 1, 2010/ } \\
\text { January 7, } 2015\end{array}$ \\
\hline $\begin{array}{l}\text { MM-111 ERBB2 } \\
\text { and ERBB3 } \\
\text { targeted }\end{array}$ & NCT00911898 & Completed phase 1 & $\begin{array}{l}\text { Advanced, refractory } \\
\text { HER2-amplified, } \\
\text { heregulin-positive } \\
\text { cancers }\end{array}$ & & $\begin{array}{l}\text { Merrimack } \\
\quad \text { Pharmaceuticals }\end{array}$ & $\begin{array}{l}\text { June } 3,2009 / \\
\quad \text { January } 13,2015\end{array}$ \\
\hline $\begin{array}{c}\text { MM-141 IGF1R and } \\
\text { ERBB3 targeted }\end{array}$ & NCT01733004 & Completed phase 1 & $\begin{array}{l}\text { Hepatocellular } \\
\text { carcinoma }\end{array}$ & & $\begin{array}{l}\text { Merrimack } \\
\text { Pharmaceuticals }\end{array}$ & $\begin{array}{c}\text { November 26, 2012/ } \\
\text { August 4, } 2016\end{array}$ \\
\hline $\begin{array}{l}\text { MCLA-128 ERBB2 } \\
\text { and ERBB3 } \\
\text { targeted }\end{array}$ & NCT03321981 & Recruiting phase 2 & $\begin{array}{l}\text { Breast cancer } \\
\text { metastatic }\end{array}$ & $\begin{array}{l}\text { Trastuzumab, } \\
\text { vinorelbine, } \\
\text { endocrine therapy }\end{array}$ & Merus N.V. & $\begin{array}{l}\text { October } 26,2017 / \\
\text { August } 13,2018\end{array}$ \\
\hline
\end{tabular}

Data available at https://clinicaltrials.gov (last accessed March 5, 2019).

BRAF, serine/threonine-protein kinase B-raf; EGFR, epidermal growth factor receptor; ER, estrogen receptor; HER, human EGFR; HRG, histidine-rich glycoprotein; I-SPY 2 Trial, Investigation of Serial Studies to Predict Your Therapeutic Response With Imaging And moLecular Analysis 2; NSCLC, nonsmall-cell lung carcinoma.

facilitated therapeutic resistance in ERBB2-driven breast cancers, a similar role was elucidated for ERBB3 in EGFRdriven lung cancers. ${ }^{98}$ These observations led to the development of monoclonal antibodies that simultaneously target EGFR and ERBB3 [duligotuzumab (MEHD7945A)] or ERBB2 and ERBB3 (MM-111, MCLA-128) (Table 1).

Despite these advances, several important questions essential for the future design of ERBB3-directed therapeutic agents remain unanswered. For example, although there is evidence that patients with specific mutations in the tyrosine kinase domain of ERBB3 mutations respond better to ERBB inhibitors, ${ }^{99}$ how mutations at other sites effect responsiveness to these agents is unknown. In addition, it is unclear whether common somatic mutations of ERBB3 have structural consequences that affect endodomain phosphorylation and drug responsiveness. Therapeutic resistance in ERBB-expressing tumors does not always occur via mechanisms such as outlined above. Resistance to tyrosine kinase inhibitors can also be triggered by up-regulated ERBB3 protein expression. This up-regulation occurs via multiple mechanisms. The small molecular inhibitors lapatinib and erlotinib induce ERBB3 expression by promoting 
forkhead box protein $\mathrm{O}-$ mediated transcription. ${ }^{100}$ Rapamycin enhances ERBB3 expression by repressing the expression of miRNAs that regulate ERBB3 mRNA levels or by promoting $\mathrm{PI} 3 \mathrm{~K}-$ mammalian target of rapamycin-eukaryotic translation initiation factor 4E-binding protein 1 mediated up-regulation of $5^{\prime}$ cap-binding translation, ${ }^{101}$ whereas inhibitors of mTOR kinases, such as PP242 and BE235, enhance ERBB3 phosphorylation by decreasing phosphatase activity. ${ }^{101}$ Given the intricate regulation of ERBB3 action that we have described herein, it is not surprising that we continue to encounter unexpected mechanisms by which ERBB3 promotes tumorigenesis or therapeutic resistance. This is likely to be an important field of investigation for many years to come.

\section{References}

1. Carlin CR, Knowles BB: Identity of human epidermal growth factor (EGF) receptor with glycoprotein SA-7: evidence for differential phosphorylation of the two components of the EGF receptor from A431 cells. Proc Natl Acad Sci U S A 1982, 79:5026-5030

2. Downward J, Yarden Y, Mayes E, Scrace G, Totty N, Stockwell P, Ullrich A, Schlessinger J, Waterfield MD: Close similarity of epidermal growth factor receptor and v-erb-B oncogene protein sequences. Nature 1984, 307:521-527

3. Ullrich A, Coussens L, Hayflick JS, Dull TJ, Gray A, Tam AW, Lee J, Yarden Y, Libermann TA, Schlessinger J, Downward J, Mayes ELB, Whittle N, Waterfield MD, Seeburg PH: Human epidermal growth factor receptor cDNA sequence and aberrant expression of the amplified gene in A431 epidermoid carcinoma cells. Nature 1984, 309:418-425

4. Coussens L, Yang-Feng TL, Liao YC, Chen E, Gray A, McGrath J, Seeburg PH, Libermann TA, Schlessinger J, Francke U, Levinson A, Ullrich A: Tyrosine kinase receptor with extensive homology to EGF receptor shares chromosomal location with neu oncogene. Science 1985, 230:1132-1139

5. Kraus MH, Issing W, Miki T, Popescu NC, Aaronson SA: Isolation and characterization of ERBB3, a third member of the ERBB/epidermal growth factor receptor family: evidence for overexpression in a subset of human mammary tumors. Proc Natl Acad Sci U S A 1989, 86:9193-9197

6. Plowman GD, Whitney GS, Neubauer MG, Green JM, McDonald VL, Todaro GJ, Shoyab M: Molecular cloning and expression of an additional epidermal growth factor receptor-related gene. Proc Natl Acad Sci U S A 1990, 87:4905-4909

7. Plowman GD, Culouscou JM, Whitney GS, Green JM, Carlton GW, Foy L, Neubauer MG, Shoyab M: Ligand-specific activation of HER4/p180erbB4, a fourth member of the epidermal growth factor receptor family. Proc Natl Acad Sci U S A 1993, 90:1746-1750

8. Olayioye MA, Neve RM, Lane HA, Hynes NE: The ErbB signaling network: receptor heterodimerization in development and cancer. EMBO J 2000, 19:3159-3167

9. Gerecke KM, Wyss JM, Karavanova I, Buonanno A, Carroll SL: ErbB transmembrane tyrosine kinase receptors are differentially expressed throughout the adult rat central nervous system. J Comp Neurol 2001, 433:86-100

10. Hynes NE, MacDonald G: ErbB receptors and signaling pathways in cancer. Curr Opin Cell Biol 2009, 21:177-184

11. Kaushansky A, Gordus A, Budnik BA, Lane WS, Rush J, MacBeath G: System-wide investigation of ErbB4 reveals 19 sites of Tyr phosphorylation that are unusually selective in their recruitment properties. Chem Biol 2008, 15:808-817
12. Kovacs E, Das R, Wang Q, Collier TS, Cantor A, Huang Y, Wong K, Mirza A, Barros T, Grob P, Jura N, Bose R, Kuriyan J: Analysis of the role of the $\mathrm{C}$-terminal tail in the regulation of the epidermal growth factor receptor. Mol Cell Biol 2015, 35:3083-3102

13. Jorissen RN, Walker F, Pouliot N, Garrett TP, Ward CW, Burgess AW: Epidermal growth factor receptor: mechanisms of activation and signalling. Exp Cell Res 2003, 284:31-53

14. Vecchi M, Carpenter G: Constitutive proteolysis of the ErbB-4 receptor tyrosine kinase by a unique, sequential mechanism. J Cell Biol 1997, 139:995-1003

15. Rio C, Buxbaum JD, Peschon JJ, Corfas G: Tumor necrosis factoralpha-converting enzyme is required for cleavage of erbB4/HER4. J Biol Chem 2000, 275:10379-10387

16. Ni CY, Murphy MP, Golde TE, Carpenter G: gamma-Secretase cleavage and nuclear localization of ErbB-4 receptor tyrosine kinase. Science 2001, 294:2179-2181

17. Lee HJ, Jung KM, Huang YZ, Bennett LB, Lee JS, Mei L, Kim TW: Presenilin-dependent gamma-secretase-like intramembrane cleavage of ErbB4. J Biol Chem 2002, 277:6318-6323

18. Naresh A, Long W, Vidal GA, Wimley WC, Marrero L, Sartor CI, Tovey S, Cooke TG, Bartlett JM, Jones FE: The ERBB4/HER4 intracellular domain 4ICD is a BH3-only protein promoting apoptosis of breast cancer cells. Cancer Res 2006, 66:6412-6420

19. Naresh A, Thor AD, Edgerton SM, Torkko KC, Kumar R, Jones FE: The HER4/4ICD estrogen receptor coactivator and BH3-only protein is an effector of tamoxifen-induced apoptosis. Cancer Res 2008, 68: 6387-6395

20. Sardi SP, Murtie J, Koirala S, Patten BA, Corfas G: Presenilindependent ErbB4 nuclear signaling regulates the timing of astrogenesis in the developing brain. Cell 2006, 127:185-197

21. Sawyer C, Hiles I, Page M, Crompton M, Dean C: Two erbB-4 transcripts are expressed in normal breast and in most breast cancers. Oncogene 1998, 17:919-924

22. Elenius K, Choi CJ, Paul S, Santiestevan E, Nishi E, Klagsbrun M: Characterization of a naturally occurring ErbB4 isoform that does not bind or activate phosphatidyl inositol 3-kinase. Oncogene 1999, 18: $2607-2615$

23. Longo JF, Brosius SN, Black L, Worley SH, Wilson RC, Roth KA, Carroll SL: ErbB4 promotes malignant peripheral nerve sheath tumor pathogenesis via Ras-independent mechanisms. Cell Communi Signal 2019, 17:74

24. Nielsen TO, Sorensen S, Dagnaes-Hansen F, Kjems J, Sorensen BS: Directing HER4 mRNA expression towards the CYT2 isoform by antisense oligonucleotide decreases growth of breast cancer cells in vitro and in vivo. Br J Cancer 2013, 108:2291-2298

25. Stein RA, Staros JV: Insights into the evolution of the ErbB receptor family and their ligands from sequence analysis. BMC Evol Biol 2006, 6:79

26. Carraway KL, Theodoropoulos G, Kozloski GA, Carothers Carraway CA: Muc4/MUC4 functions and regulation in cancer. Future Oncol 2009, 5:1631-1640

27. Lemmon MA: Ligand-induced ErbB receptor dimerization. Exp Cell Res 2009, 315:638-648

28. Ward CW, Garrett TP: The relationship between the L1 and L2 domains of the insulin and epidermal growth factor receptors and leucine-rich repeat modules. BMC Bioinformatics 2001, 2:4

29. Ferguson KM, Berger MB, Mendrola JM, Cho HS, Leahy DJ, Lemmon MA: EGF activates its receptor by removing interactions that autoinhibit ectodomain dimerization. Mol Cell 2003, 11:507-517

30. Zhang X, Gureasko J, Shen K, Cole PA, Kuriyan J: An allosteric mechanism for activation of the kinase domain of epidermal growth factor receptor. Cell 2006, 125:1137-1149

31. Ogiso H, Ishitani R, Nureki O, Fukai S, Yamanaka M, Kim JH, Saito K, Sakamoto A, Inoue M, Shirouzu M, Yokoyama S: Crystal structure of the complex of human epidermal growth factor and receptor extracellular domains. Cell 2002, 110:775-787 
32. Ward MD, Leahy DJ: Kinase activator-receiver preference in ErbB heterodimers is determined by intracellular regions and is not coupled to extracellular asymmetry. J Biol Chem 2015, 290:1570-1579

33. Jura N, Endres NF, Engel K, Deindl S, Das R, Lamers MH, Wemmer DE, Zhang X, Kuriyan J: Mechanism for activation of the EGF receptor catalytic domain by the juxtamembrane segment. Cell 2009, 137:1293-1307

34. Red Brewer M, Choi SH, Alvarado D, Moravcevic K, Pozzi A, Lemmon MA, Carpenter G: The juxtamembrane region of the EGF receptor functions as an activation domain. Mol Cell 2009, 34: $641-651$

35. Escher C, Cymer F, Schneider D: Two GxxxG-like motifs facilitate promiscuous interactions of the human ErbB transmembrane domains. J Mol Biol 2009, 389:10-16

36. Jura N, Zhang X, Endres NF, Seeliger MA, Schindler T, Kuriyan J: Catalytic control in the EGF receptor and its connection to general kinase regulatory mechanisms. Mol Cell 2011, 42:9-22

37. Macdonald-Obermann JL, Piwnica-Worms D, Pike LJ: Mechanics of EGF receptor/ErbB2 kinase activation revealed by luciferase fragment complementation imaging. Proc Natl Acad Sci U S A 2012, 109:137-142

38. Kovacs E, Zorn JA, Huang Y, Barros T, Kuriyan J: A structural perspective on the regulation of the epidermal growth factor receptor. Annu Rev Biochem 2015, 84:739-764

39. Qiu C, Tarrant MK, Choi SH, Sathyamurthy A, Bose R, Banjade S, Pal A, Bornmann WG, Lemmon MA, Cole PA, Leahy DJ: Mechanism of activation and inhibition of the HER4/ErbB4 kinase. Structure 2008, 16:460-467

40. Linggi B, Carpenter G: ErbB receptors: new insights on mechanisms and biology. Trends Cell Biol 2006, 16:649-656

41. Brossier NM, Byer SJ, Peavler LT, Carroll SL: ErbB membrane tyrosine kinase receptors: analyzing migration in a highly complex signaling system. Protein Kinase Technologies: Neuromethods, vol 68. Edited by Mukai H. Totowa, NJ: Humana Press, 2012. pp. 105-131

42. Yarden Y, Pines G: The ERBB network: at last, cancer therapy meets systems biology. Nat Rev Cancer 2012, 12:553-563

43. Hu S, Sun Y, Meng Y, Wang X, Yang W, Fu W, Guo H, Qian W, Hou S, Li B, Rao Z, Lou Z, Guo Y: Molecular architecture of the ErbB2 extracellular domain homodimer. Oncotarget 2015, 6:1695-1706

44. Freed DM, Bessman NJ, Kiyatkin A, Salazar-Cavazos E, Byrne PO, Moore JO, Valley CC, Ferguson KM, Leahy DJ, Lidke DS, Lemmon MA: EGFR ligands differentially stabilize receptor dimers to specify signaling kinetics. Cell 2017, 171:683-695.e18

45. Monsey J, Shen W, Schlesinger P, Bose R: Her4 and Her2/neu tyrosine kinase domains dimerize and activate in a reconstituted in vitro system. J Biol Chem 2010, 285:7035-7044

46. Riethmacher D, Sonnenberg-Riethmacher E, Brinkmann V, Yamaai T, Lewin GR, Birchmeier C: Severe neuropathies in mice with targeted mutations in the ErbB3 receptor. Nature 1997, 389: $725-730$

47. Erickson SL, O'Shea KS, Ghaboosi N, Loverro L, Frantz G, Bauer M, Lu LH, Moore MW: ErbB3 is required for normal cerebellar and cardiac development: a comparison with ErbB2- and heregulin-deficient mice. Development 1997, 124:4999-5011

48. Britsch S, Li L, Kirchhoff S, Theuring F, Brinkmann V, Birchmeier C, Riethmacher D: The ErbB2 and ErbB3 receptors and their ligand, neuregulin-1, are essential for development of the sympathetic nervous system. Genes Dev 1998, 12:1825-1836

49. Gassmann M, Casagranda F, Orioli D, Simon H, Lai C, Klein R, Lemke G: Aberrant neural and cardiac development in mice lacking the ErbB4 neuregulin receptor. Nature 1995, 378:390-394

50. Meyer D, Birchmeier C: Multiple essential functions of neuregulin in development. Nature 1995, 378:386-390

51. Balko JM, Miller TW, Morrison MM, Hutchinson K, Young C, Rinehart C, Sanchez V, Jee D, Polyak K, Prat A, Perou CM, Arteaga CL, Cook RS: The receptor tyrosine kinase ErbB3 maintains the balance between luminal and basal breast epithelium. Proc Natl Acad Sci U S A 2012, 109:221-226

52. Fock V, Plessl K, Draxler P, Otti GR, Fiala C, Knofler M, Pollheimer J: Neuregulin-1-mediated ErbB2-ErbB3 signalling protects human trophoblasts against apoptosis to preserve differentiation. J Cell Sci 2015, 128:4306-4316

53. Takahashi M, Hasegawa Y, Ikeda Y, Wada Y, Tajiri M, Ariki S, Takamiya R, Nishitani C, Araki M, Yamaguchi Y, Taniguchi N, Kuroki Y: Suppression of heregulin beta signaling by the single $\mathrm{N}$-glycan deletion mutant of soluble ErbB3 protein. J Biol Chem 2013, 288:32910-32921

54. Lee HS, Qi Y, Im W: Effects of N-glycosylation on protein conformation and dynamics: protein Data Bank analysis and molecular dynamics simulation study. Sci Rep 2015, 5:8926

55. Yokoe S, Takahashi M, Asahi M, Lee SH, Li W, Osumi D, Miyoshi E, Taniguchi N: The Asn418-linked N-glycan of ErbB3 plays a crucial role in preventing spontaneous heterodimerization and tumor promotion. Cancer Res 2007, 67:1935-1942

56. Wieduwilt MJ, Moasser MM: The epidermal growth factor receptor family: biology driving targeted therapeutics. Cell Mol Life Sci 2008, 65:1566-1584

57. Vakar-Lopez F, Cheng CJ, Kim J, Shi GG, Troncoso P, Tu SM, YuLee LY, Lin SH: Up-regulation of MDA-BF-1, a secreted isoform of ErbB3, in metastatic prostate cancer cells and activated osteoblasts in bone marrow. J Pathol 2004, 203:688-695

58. Koumakpayi IH, Diallo JS, Le Page C, Lessard L, Gleave M, Begin LR, Mes-Masson AM, Saad F: Expression and nuclear localization of ErbB3 in prostate cancer. Clin Cancer Res 2006, 12: $2730-2737$

59. Adilakshmi T, Ness-Myers J, Madrid-Aliste C, Fiser A, Tapinos N: A nuclear variant of ErbB3 receptor tyrosine kinase regulates ezrin distribution and Schwann cell myelination. J Neurosci 2011, 31: $5106-5119$

60. El Maassarani M, Barbarin A, Fromont G, Kaissi O, Lebbe M, Vannier B, Moussa A, Seite P: Integrated and functional genomics analysis validates the relevance of the nuclear variant ErbB380kDa in prostate cancer progression. PLoS One 2016, 11:e0155950

61. Andrique L, Fauvin D, El Maassarani M, Colasson $\mathrm{H}$, Vannier B, Seite P: ErbB3(80 kDa), a nuclear variant of the ErbB3 receptor, binds to the cyclin D1 promoter to activate cell proliferation but is negatively controlled by p14ARF. Cell Signal 2012, 24:1074-1085

62. Sithanandam G, Anderson LM: The ERBB3 receptor in cancer and cancer gene therapy. Cancer Gene Ther 2008, 15:413-448

63. Guy PM, Platko JV, Cantley LC, Cerione RA, Carraway KL 3rd: Insect cell-expressed p180erbB3 possesses an impaired tyrosine kinase activity. Proc Natl Acad Sci U S A 1994, 91:8132-8136

64. Scheeff ED, Eswaran J, Bunkoczi G, Knapp S, Manning G: Structure of the pseudokinase VRK3 reveals a degraded catalytic site, a highly conserved kinase fold, and a putative regulatory binding site. Structure 2009, 17:128-138

65. Zhang Q, Park E, Kani K, Landgraf R: Functional isolation of activated and unilaterally phosphorylated heterodimers of ERBB2 and ERBB3 as scaffolds in ligand-dependent signaling. Proc Natl Acad Sci U S A 2012, 109:13237-13242

66. Littlefield P, Liu L, Mysore V, Shan Y, Shaw DE, Jura N: Structural analysis of the EGFR/HER3 heterodimer reveals the molecular basis for activating HER3 mutations. Sci Signal 2014, 7:ra114

67. Shi F, Telesco SE, Liu Y, Radhakrishnan R, Lemmon MA: ErbB3/HER3 intracellular domain is competent to bind ATP and catalyze autophosphorylation. Proc Natl Acad Sci U S A 2010, 107: $7692-7697$

68. Jura N, Shan Y, Cao X, Shaw DE, Kuriyan J: Structural analysis of the catalytically inactive kinase domain of the human EGF receptor 3. Proc Natl Acad Sci U S A 2009, 106:21608-21613

69. Telesco SE, Shih A, Liu Y, Radhakrishnan R: Investigating molecular mechanisms of activation and mutation of the HER2 receptor tyrosine 
kinase through computational modeling and simulation. Cancer Res $\mathrm{J}$ 2011, 4:1-35

70. Stortelers C, van der Woning SP, Jacobs-Oomen S, Wingens M, van Zoelen EJ: Selective formation of ErbB-2/ErbB-3 heterodimers depends on the ErbB-3 affinity of epidermal growth factor-like ligands. J Biol Chem 2003, 278:12055-12063

71. Roskoski R Jr: The ErbB/HER family of protein-tyrosine kinases and cancer. Pharmacol Res 2014, 79:34-74

72. Sak MM, Breen K, Ronning SB, Pedersen NM, Bertelsen V, Stang E, Madshus IH: The oncoprotein ErbB3 is endocytosed in the absence of added ligand in a clathrin-dependent manner. Carcinogenesis 2012, 33:1031-1039

73. Landgraf R, Eisenberg D: Heregulin reverses the oligomerization of HER3. Biochemistry 2000, 39:8503-8511

74. van Lengerich B, Agnew C, Puchner EM, Huang B, Jura N: EGF and NRG induce phosphorylation of HER3/ERBB3 by EGFR using distinct oligomeric mechanisms. Proc Natl Acad Sci U S A 2017, 114:E2836-E2845

75. Cao Z, Wu X, Yen L, Sweeney C, Carraway KL 3rd: Neuregulininduced ErbB3 downregulation is mediated by a protein stability cascade involving the E3 ubiquitin ligase Nrdp1. Mol Cell Biol 2007, 27:2180-2188

76. Fry WH, Simion C, Sweeney C, Carraway KL 3rd: Quantity control of the ErbB3 receptor tyrosine kinase at the endoplasmic reticulum. Mol Cell Biol 2011, 31:3009-3018

77. Baulida J, Carpenter G: Heregulin degradation in the absence of rapid receptor-mediated internalization. Exp Cell Res 1997, 232:167-172

78. Reif R, Adawy A, Vartak N, Schroder J, Gunther G, Ghallab A, Schmidt M, Schormann W, Hengstler JG: Activated ErbB3 translocates to the nucleus via clathrin-independent endocytosis, which is associated with proliferating cells. J Biol Chem 2016, 291:3837-3847

79. Holbro T, Beerli RR, Maurer F, Koziczak M, Barbas CF 3rd, Hynes NE: The ErbB2/ErbB3 heterodimer functions as an oncogenic unit: ErbB2 requires ErbB3 to drive breast tumor cell proliferation. Proc Natl Acad Sci U S A 2003, 100:8933-8938

80. Citri A, Skaria KB, Yarden Y: The deaf and the dumb: the biology of ErbB-2 and ErbB-3. Exp Cell Res 2003, 284:54-65

81. Liles JS, Arnoletti JP, Tzeng CW, Howard JH, Kossenkov AV, Kulesza P, Heslin MJ, Frolov A: ErbB3 expression promotes tumorigenesis in pancreatic adenocarcinoma. Cancer Biol Ther 2010 , 10:555-563

82. Schulze WX, Deng L, Mann M: Phosphotyrosine interactome of the ErbB-receptor kinase family. Mol Syst Biol 2005, 1:2005.0008

83. Mishra R, Hanker AB, Garrett JT: Genomic alterations of ERBB receptors in cancer: clinical implications. Oncotarget 2017, 8: $114371-114392$

84. Jaiswal BS, Kljavin NM, Stawiski EW, Chan E, Parikh C, Durinck S, Chaudhuri S, Pujara K, Guillory J, Edgar KA, Janakiraman V, Scholz RP, Bowman KK, Lorenzo M, Li H, Wu J, Yuan W, Peters BA, Kan Z, Stinson J, Mak M, Modrusan Z, Eigenbrot C, Firestein R, Stern HM, Rajalingam K, Schaefer G, Merchant MA, Sliwkowski MX, de Sauvage FJ, Seshagiri S: Oncogenic ERBB3 mutations in human cancers. Cancer Cell 2013, 23:603-617

85. Karachaliou N, Lazzari C, Verlicchi A, Sosa AE, Rosell R: HER3 as a therapeutic target in cancer. BioDrugs 2017, 31:63-73

86. Mota JM, Collier KA, Barros Costa RL, Taxter T, Kalyan A, Leite CA, Chae YK, Giles FJ, Carneiro BA: A comprehensive review of heregulins, HER3, and HER4 as potential therapeutic targets in cancer. Oncotarget 2017, 8:89284-89306

87. Humtsoe JO, Pham E, Louie RJ, Chan DA, Kramer RH: ErbB3 upregulation by the HNSCC 3D microenvironment modulates cell survival and growth. Oncogene 2016, 35:1554-1564

88. Jacobi N, Seeboeck R, Hofmann E, Schweiger H, Smolinska V, Mohr T, Boyer A, Sommergruber W, Lechner P, Pichler-
Huebschmann C, Onder K, Hundsberger H, Wiesner C, Eger A: Organotypic three-dimensional cancer cell cultures mirror drug responses in vivo: lessons learned from the inhibition of EGFR signaling. Oncotarget 2017, 8:107423-107440

89. Sarup J, Jin P, Turin L, Bai X, Beryt M, Brdlik C, Higaki JN, Jorgensen B, Lau FW, Lindley P, Liu J, Ni I, Rozzelle J, Kumari R, Watson SA, Zhang J, Shepard HM: Human epidermal growth factor receptor (HER-1:HER-3) Fc-mediated heterodimer has broad antiproliferative activity in vitro and in human tumor xenografts. Mol Cancer Ther 2008, 7:3223-3236

90. Mishra R, Patel H, Alanazi S, Yuan L, Garrett JT: HER3 signaling and targeted therapy in cancer. Oncol Rev 2018, 12:355

91. Wu Y, Zhang Y, Wang M, Li Q, Qu Z, Shi V, Kraft P, Kim S, Gao Y, Pak J, Youngster S, Horak ID, Greenberger LM: Downregulation of HER3 by a novel antisense oligonucleotide, EZN-3920, improves the antitumor activity of EGFR and HER2 tyrosine kinase inhibitors in animal models. Mol Cancer Ther 2013, 12:427-437

92. Xie T, Lim SM, Westover KD, Dodge ME, Ercan D, Ficarro SB, Udayakumar D, Gurbani D, Tae HS, Riddle SM, Sim T, Marto JA, Janne PA, Crews CM, Gray NS: Pharmacological targeting of the pseudokinase Her3. Nat Chem Biol 2014, 10:1006-1012

93. Capone E, Giansanti F, Ponziani S, Lamolinara A, Iezzi M, Cimini A, Angelucci F, Sorda R, Laurenzi V, Natali PG, Ippoliti R, Iacobelli S, Sala G: EV20-Sap, a novel anti-HER-3 antibody-drug conjugate, displays promising antitumor activity in melanoma. Oncotarget 2017 , 8:95412-95424

94. Capone E, Lamolinara A, D’Agostino D, Rossi C, De Laurenzi V, Iezzi M, Iacobelli S, Sala G: EV20-mediated delivery of cytotoxic auristatin MMAF exhibits potent therapeutic efficacy in cutaneous melanoma. J Control Release 2018, 277:48-56

95. Yonesaka K, Takegawa N, Watanabe S, Haratani K, Kawakami H, Sakai K, Chiba Y, Maeda N, Kagari T, Hirotani K, Nishio K, Nakagawa K: An HER3-targeting antibody-drug conjugate incorporating a DNA topoisomerase I inhibitor U3-1402 conquers EGFR tyrosine kinase inhibitor-resistant NSCLC. Oncogene 2019, 38:1398-1409

96. Miller MJ, Foy KC, Overholser JP, Nahta R, Kaumaya PT: HER-3 peptide vaccines/mimics: combined therapy with IGF-1R, HER-2, and HER-1 peptides induces synergistic antitumor effects against breast and pancreatic cancer cells. Oncoimmunology 2014, 3: e956012

97. Martins CD, Da Pieve C, Burley TA, Smith R, Ciobota DM, Allott L, Harrington KJ, Oyen WJG, Smith G, Kramer-Marek G: HER3mediated resistance to Hsp90 inhibition detected in breast cancer xenografts by affibody-based PET imaging. Clin Cancer Res 2018, $24: 1853-1865$

98. Hamburger AW: The role of ErbB3 and its binding partners in breast cancer progression and resistance to hormone and tyrosine kinase directed therapies. J Mammary Gland Biol Neoplasia 2008, 13: $225-233$

99. Verlingue L, Hollebecque A, Lacroix L, Postel-Vinay S, Varga A, El Dakdouki Y, Baldini C, Balheda R, Gazzah A, Michot JM, Marabelle A, Mir O, Arnedos M, Rouleau E, Solary E, De Baere T, Angevin E, Armand JP, Michiels S, Andre F, Deutsch E, Scoazec JY, Soria JC, Massard C: Human epidermal receptor family inhibitors in patients with ERBB3 mutated cancers: entering the back door. Eur J Cancer 2018, 92:1-10

100. Amin DN, Sergina N, Lim L, Goga A, Moasser MM: HER3 signalling is regulated through a multitude of redundant mechanisms in HER2-driven tumour cells. Biochem J 2012, 447:417-425

101. Lyu H, Huang J, Edgerton SM, Thor AD, He Z, Liu B: Increased erbB3 promotes erbB2/neu-driven mammary tumor proliferation and co-targeting of erbB2/erbB3 receptors exhibits potent inhibitory effects on breast cancer cells. Int J Clin Exp Pathol 2015, 8: 6143-6156 